\title{
Holocene dynamics of the Rhone Glacier, Switzerland, deduced from ice flow models and cosmogenic nuclides
}

\author{
Brent M. Goehring ${ }^{\mathrm{a}, *}$, David A. Vacco ${ }^{a}$, Richard B. Alley ${ }^{\mathrm{a}}$, Joerg M. Schaefer ${ }^{\mathrm{b}}$ \\ a Department of Geosciences, Earth and Environmental Systems Institute, Pennsylvania State University, University Park, PA 16802, USA \\ ${ }^{\mathrm{b}}$ Lamont-Doherty Earth Observatory of Columbia University, Palisades, NY 10964, USA
}

\section{A R T I C L E I N F O}

\section{Article history:}

Received 18 February 2012

Received in revised form

16 July 2012

Accepted 17 July 2012

Editor: J. Lynch-Stieglitz

\section{Keywords:}

Rhone Glacier

in situ ${ }^{14} \mathrm{C}$

${ }^{10} \mathrm{Be}$

Holocene

\begin{abstract}
A B S T R A C T
We describe efforts to model the Holocene extent of the Rhone Glacier, Switzerland, using four paleoclimate records as templates for paleo-equilibrium line altitude to identify candidate driving mechanisms of glaciers in the Alps. We evaluate the success of each paleoclimate template by comparing cosmogenic ${ }^{10} \mathrm{Be}$ and ${ }^{14} \mathrm{C}$ concentrations in pro-glacial bedrock derived from modeled glacier configurations to measured values. An adequate fit can be obtained using mean summer insolation for $46.5^{\circ} \mathrm{N}$. However, use of the Dongee Cave, China, speleothem record yields the best fit by accounting for both sub-millennial (e.g. Little Ice Age and Medieval Warm Period) and multi-millennial climate variations (summer insolation). Our result indicates that glaciers in the Alps primarily responded to changes in insolation during the Holocene were smaller than today during the early Holocene when insolation was relatively high, and became larger during the mid to late Holocene. Superimposed on the first-order insolation response were shorter, sometimes large amplitude, length changes in response to short-lived climate events such as the Medieval Warm Period and the LIA.
\end{abstract}

(c) 2012 Elsevier B.V. All rights reserved.

\section{Introduction}

Better understanding of the sensitivity of glaciers to climate change can reduce uncertainties in projections of future variations. Glacier-climate interaction during the Holocene epoch, the interval spanning the last $\sim 11,500$ years, presents an ideal natural experiment. Glaciers typically respond sensitively and rapidly to small climate changes (Oerlemans, 2005) and are among the few environmental systems with well-documented reactions to the relatively small-amplitude/short-duration changes of the Holocene. However, climate histories from glaciers primarily record intervals when the ice was relatively large, as documented in ages of moraines (e.g. Licciardi et al., 2009; Schaefer et al., 2009). Accurate, comprehensive chronologies of Holocene glacier length changes remain scarce.

Approaches used to reconstruct the fluctuations of glaciers include records of clastic sedimentation to proglacial lakes (e.g. Leemann and Niessen, 1994; Menounos et al., 2008; Nesje et al., 2001; Osborn et al., 2007) and radiocarbon dating and dendrochronologic analysis of fossil trees or other organic materials that grew up-valley of the modern glacier terminus and were killed during a subsequent re-advance (e.g. Holzhauser et al., 2005; Hormes et al.,

\footnotetext{
* Corresponding author. Now at: Department of Earth and Atmospheric Sciences, Purdue University, West Lafayette, IN 47907, USA.

Tel.: +1 7654940258

E-mail address: bgoehrin@purdue.edu (B.M. Goehring).
}

2001; Joerin et al., 2006; Osborn et al., 2007). Although these approaches have improved our understanding of Holocene glacier dynamics substantially, the interpretation of glacier size from clastic lake-sediments is primarily qualitative rather than quantitative. Only in cases where sedimentation is limited by glacier size (e.g. inflow occurs only when a glacier advances beyond a sill) can constraints be placed on glacier length. Otherwise interpretations of glacier length are inferred from sediment volumes/grain size. Comprehensive fossil-tree records have so far been produced for only a few localities (e.g. Holzhauser et al., 2005; Hormes et al., 2001; Joerin et al., 2006; Osborn et al., 2007). Furthermore, the information from these records yields only limiting estimates of the ice extent during Holocene warm periods.

In an effort to understand the duration that glaciers were smaller or larger than their modern extents, Goehring et al. (2011) used in situ ${ }^{14} \mathrm{C}$ and ${ }^{10} \mathrm{Be}$ from proglacial bedrock to determine the duration during the Holocene that the Rhone Glacier, Switzerland, was smaller or larger than its modern extent. Exposure of the bedrock allows for cosmic-ray production of both ${ }^{14} \mathrm{C}$ and ${ }^{10} \mathrm{Be}$, subglacial erosion removes both, but the much shorter half-life of ${ }^{14} \mathrm{C}$ means that it is preferentially lost during subglacial burial. Therefore, the modern measured ${ }^{14} \mathrm{C}$ and ${ }^{10} \mathrm{Be}$ concentrations represent the integrated exposure and burial history of the sample sites due to fluctuations of the Rhone Glacier. By sampling a transect across the glacial trough (Fig. 1), Goehring et al. (2011) determined that the Rhone Glacier had a smaller extent than today for roughly $60 \%$ of the Holocene $(6.5 \pm 1.9$ kyr smaller vs. $4.5 \pm 1.9$ kyr larger $)$. 

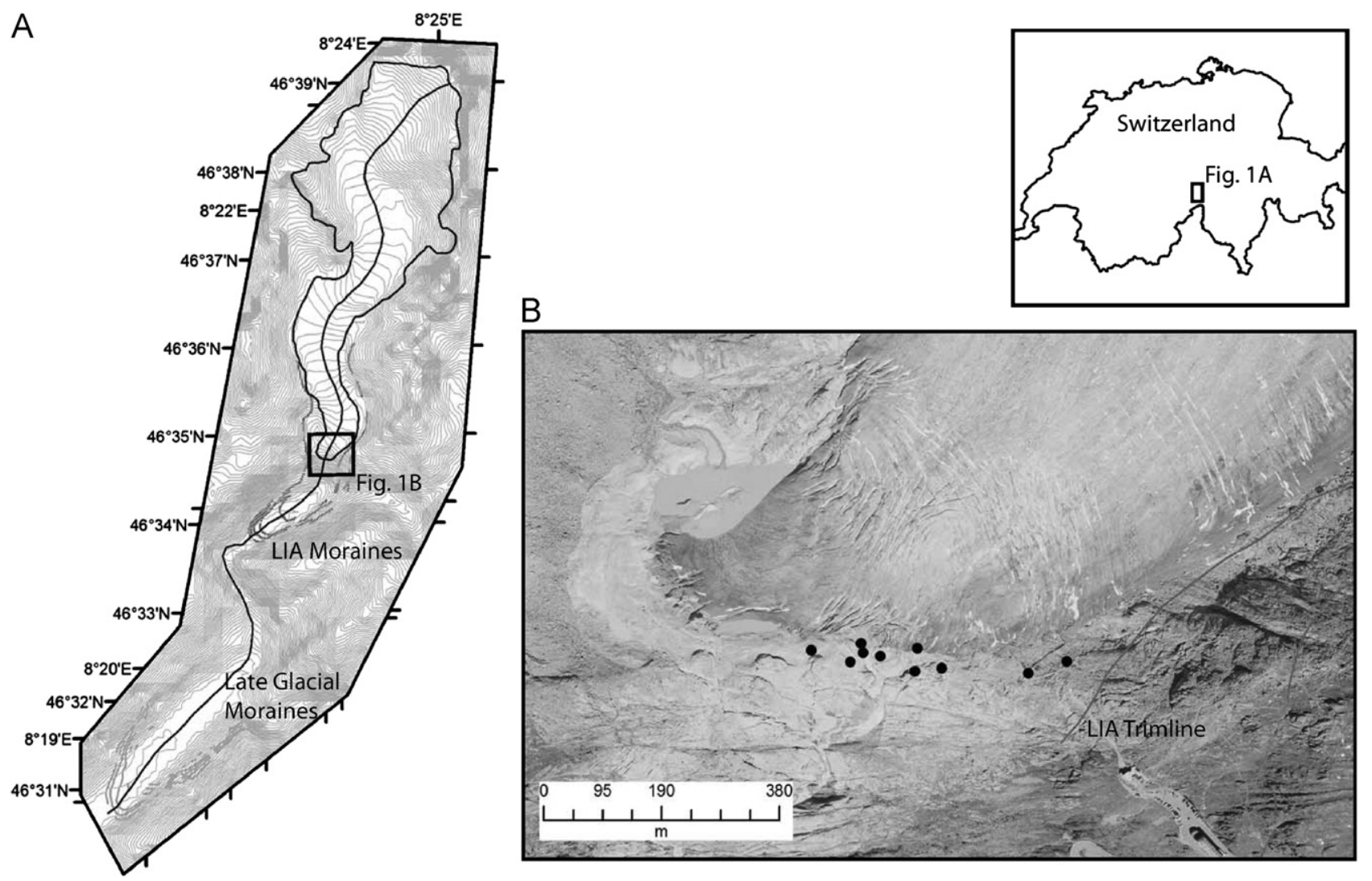

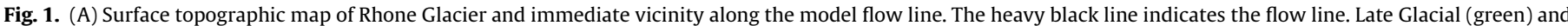

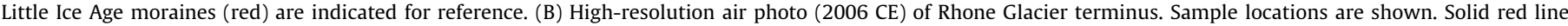
indicates approximate ice extension during recent times (ca. $1950 \mathrm{CE}$ ).

From this integrated exposure and burial duration, Goehring et al. (2011) identified an overly simple, but candidate climate scenario (exposure during the early Holocene, and dominantly ice covered since 4-5 ka) consistent with their ${ }^{14} \mathrm{C}$ and ${ }^{10} \mathrm{Be}$ concentrations. Unfortunately, the driving climatic variations could not be identified in their work, with much of the uncertainty arising from lack of knowledge of when during the Holocene the exposure occurred.

Paleoclimatic anomalies often are spatially correlated over long distances-for example, the Little Ice Age cooling affected most of the Northern Hemisphere (e.g. Mann et al., 2009), and mid-Holocene northern warmth was widespread (e.g. Miller et al., 2010, Section 12.1). Thus, an appropriately chosen and calibrated paleoclimate record can serve as a template for the timing of climate changes affecting a glacier. We explore this possibility by modeling the advance and retreat history of the Rhone Glacier over the Late Glacial and Holocene by forcing a simple 1-D numerical ice flow model with a number of candidate climate records as templates for equilibrium line altitude in an attempt to identify a likely climate scenario. We evaluate the plausibility of each of these models by comparing modeled and measured ${ }^{14} \mathrm{C}$ and ${ }^{10} \mathrm{Be}$ concentrations. Our approach of combined glacier modeling and cosmogenic nuclide measurements is similar to and motivated by the study of Ward et al. (2009). We find one candidate history that is especially promising, identify issues to be resolved in applying this methodology, and draw conclusions about the glacier history.

\section{Rhone Glacier}

The Rhone Glacier ( $\sim 9 \mathrm{~km}$ long, $\sim 17 \mathrm{~km}^{2}$ ) is one of the largest glaciers in the Swiss Alps, and forms the headwaters of the Rhone
River. During the Late Glacial Egesen Stade (Younger Dryas, 12.9$11.7 \mathrm{ka}$; Heuberger, 1966, 1968) the Rhone Glacier terminated approximately $12 \mathrm{~km}$ down-valley from its modern position. The Little Ice Age (LIA) maximum occurred circa 1860 Common Era (CE) (Hantke, 1978); the terminus was $\sim 600 \mathrm{~m}$ lower, $\sim 3 \mathrm{~km}$ down-valley, and at least $100 \mathrm{~m}$ (LIA trim-line $\sim 2400 \mathrm{~m}$ a.s.l.) of ice buried our sample sites (Fig. 1). Today, the glacier terminus is just inside a large bedrock riegel (transverse proglacial bedrock ridge).

Previous modeling of the Rhone Glacier has been performed by a number of groups (e.g. Stroeven et al., 1989; Sugiyama et al., 2007; Wallinga and van de Wal, 1998; Zahno, 2004). These studies have primarily focused on using the well-known LIA-topresent ice-margin history to tune the models to improve simulations of future responses of the Rhone Glacier to projected climate scenarios. The Rhone Glacier is also ideal for studies of responses to past climate change, including identifying candidate climate scenarios over the Holocene as is our goal in this study, because of its long observational history (glacier length, equilibrium line altitude, velocity, etc.) during a period of changing climate with amplitude typical of the Holocene climate changes.

\section{Numerical model description}

To simulate paleo Rhone Glacier configurations in response to different climate forcing, we employ a simple 1-D shallow-ice model, based on that described in Vacco et al. (2009, 2010a,b). We employ a 1-D model because it provides the primary variable of interest, glacier length, without the unneeded complexity of a 2-D or 3-D model. The 1-D model also is computationally very efficient, allowing for long model runs. 
The long observational history of the Rhone Glacier includes equilibrium line altitude (ELA), mass balance gradient along the glacier length, and climatological parameters at nearby weather stations (temperature, precipitation). Regression of ELA ( $m$ a.s.l.) against summer temperature $(\mathrm{K})$ and annual precipitation $(\mathrm{cm}$ water equivalent per year) for the period $1878 \mathrm{CE}$ to present has yielded

$\operatorname{ELA}\left(T_{s}, P_{a}\right)=2392.2+42.348 T_{s}-0.0936 P_{a}$

where $T_{s}$ is the summer temperature (June-August) and $P_{a}$ is the annual precipitation (Zahno, 2004). Additionally, the balance gradient (Chen and Funk, 1990; Wallinga and van de Wal, 1998) can be used with the ELA to calculate net mass balance along the glacier length:

$b=(S-E L A) \frac{\Delta b}{\Delta z}$

where $b$ is the net mass balance at a given elevation in $\mathrm{cm}$ water equivalent per year, $S$ is the ice surface elevation, and $\Delta b / \Delta z$ the balance gradient. We have therefore adapted the ice flow model to use this ELA and mass balance relationship, rather than calculating mass balance based on a degree day model as done in Vacco et al. (2009, 2010a,b).

The model domain is set at $25 \mathrm{~km}$ to include any readvance of the Rhone Glacier to its YD length ( $\sim 22 \mathrm{~km}$ along flowline; Fig. 1). The LIA maximum extent is recorded by a sequence of moraines near the town of Gletsch, approximately $11-12 \mathrm{~km}$ along flowline. The ${ }^{10} \mathrm{Be}$ and ${ }^{14} \mathrm{C}$ sample transect is at approximately $9.6 \mathrm{~km}$, so we consider the sample sites to be covered with no ${ }^{14} \mathrm{C}$ and ${ }^{10} \mathrm{Be}$ production when the ice extent is greater than $9.6 \mathrm{~km}$.
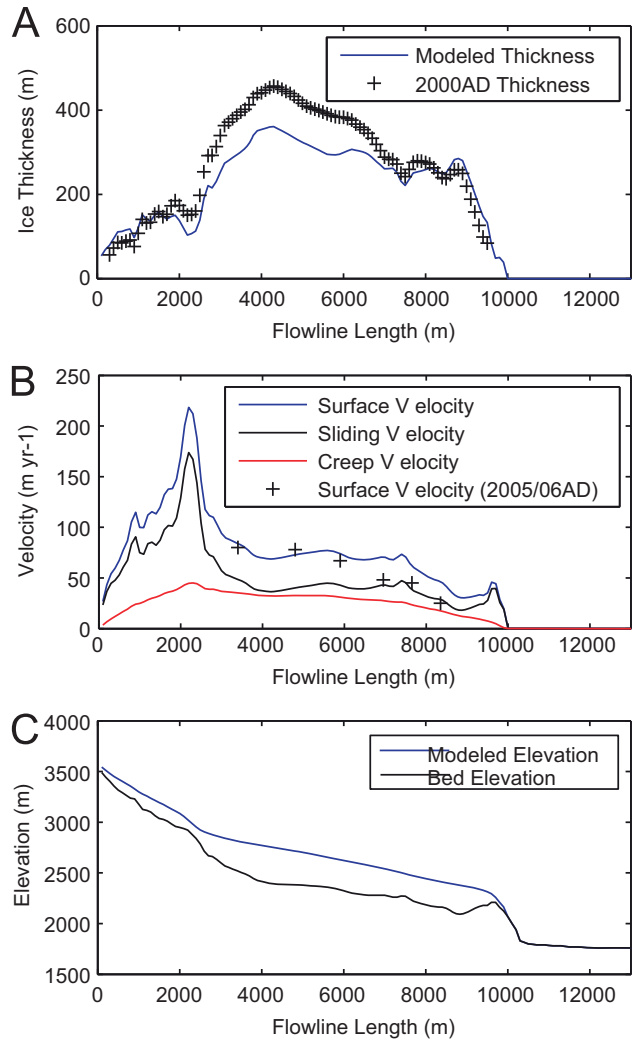

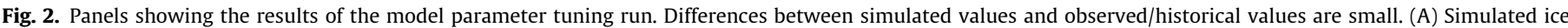

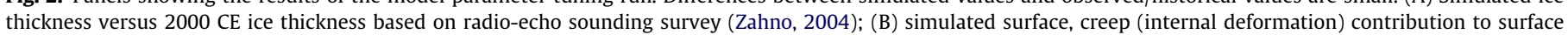

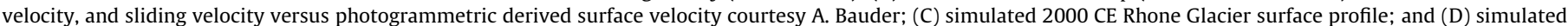
Rhone Glacier length versus historical glacier length.

\subsection{Model tuning}

Ice flow parameters within the model were tuned by trial and error, starting from values used successfully in previous models of the Rhone Glacier and other glaciers in the Alps. Performance was assessed against the known ELA and ice-extent histories during the period 1878-2002 CE, and the known ice surface velocities and ice thicknesses for $2000 \mathrm{CE}$. The best-fit model parameters are shown in Fig. 2, and summarized in Table 1. The value for ice hardness is that used in Wallinga and van de Wal (1998). We allow the model glacier to slide everywhere, and find $3 \times 10^{-3}$ $\mathrm{Pa}^{-2} \mathrm{yr}^{-1}$ to be the best fitting sliding coefficient.

During the tuning run, we first build ice to steady state at its $1878 \mathrm{CE}$ position. We then run the model forward in time by varying the ELA, based on the summer temperature and annual precipitation history recorded at two nearby meteorological stations (Chen and Funk, 1990). In the tuning run, final ice thicknesses tend to be underestimated, while ice velocities are slightly overestimated, which results in a slight underestimation of the historical glacier lengths $(\sim 100 \mathrm{~m})$. This may result from our use of a 1-D flowline model lacking drag from valley walls. Regardless, the flowline model closely reproduces measured glaciological parameters. The tuned parameters are then used in all model runs.

\subsection{Cosmogenic nuclide model}

Based on the modeled length of the Rhone Glacier, we simultaneously model the concentrations of ${ }^{14} \mathrm{C}$ and ${ }^{10} \mathrm{Be}$ in order to evaluate the success and plausibility of each candidate climate scenario. Modeling of ${ }^{10} \mathrm{Be}$ and ${ }^{14} \mathrm{C}$ buildup starts with tracking

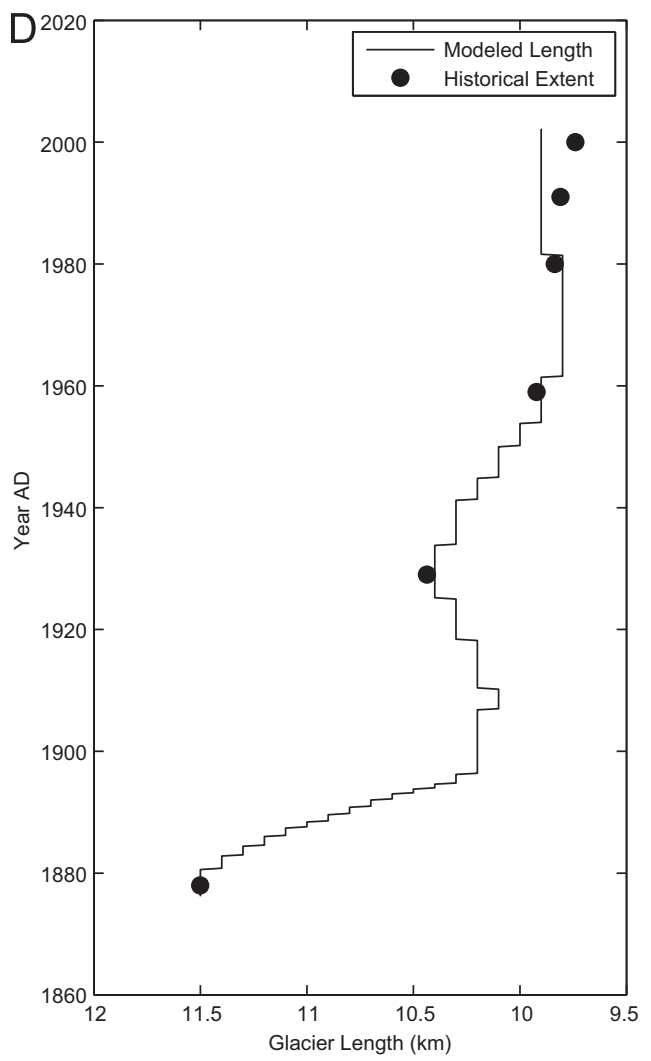


Table 1

Ice flow model parameters. Ice hardness is that used by Wallinga and van de Wal (1998). Balance gradients are based on those in Sugiyama et al. (2007).

\begin{tabular}{ll}
\hline Model parameter & Value \\
\hline Ice hardness & $9.9969 \mathrm{e}^{-18} \mathrm{~Pa}^{-3} \mathrm{yr}^{-1}$ \\
Sliding coefficient & $3 \mathrm{e}^{-3} \mathrm{~Pa}^{-2} \mathrm{yr}^{-1}$ \\
Balance gradient & > ELA: $0.0220 \mathrm{~cm}$ w.e. $\mathrm{m}^{-1}$ \\
& <ELA: $0.0170 \mathrm{~cm}$ w.e. $\mathrm{m}^{-1}$ \\
\hline
\end{tabular}

Table 2

Values of parameters used in cosmogenic nuclide model.

\begin{tabular}{lll}
\hline Parameter & Value & References \\
\hline${ }^{10}$ Be spallation P at SLHL & $4.33 \pm 0.19 \mathrm{at} \mathrm{g}^{-1} \mathrm{yr}^{-1}$ & Balco et al. (2009) \\
${ }^{14} \mathrm{C}$ spallation P at SLHL & $14.3 \pm 0.50 \mathrm{at} \mathrm{g}^{-1} \mathrm{yr}^{-1}$ & $\begin{array}{l}\text { Goehring et al. (2011), } \\
\text { Lifton et al. (2001) and } \\
\end{array}$ \\
& & $\begin{array}{l}\text { Dugan et al. (2008) } \\
\text { Gosse and Phillips (2001) }\end{array}$ \\
$\begin{array}{l}\text { Spallation attenuation } \\
\text { Fast muon attenuation }\end{array}$ & $4320 \mathrm{~g} \mathrm{~cm}^{-2}$ & Balco and Shuster (2009) \\
Negative muon & $1510 \mathrm{~g} \mathrm{~cm}^{-2}$ & Balco and Shuster (2009) \\
attenuation & $1.36 \times 10^{6} \mathrm{yr}$ & Nishiizumi et al. (2007) \\
${ }^{10}$ Be half-life & $5730 \mathrm{yr}$ & \\
${ }^{14} \mathrm{C}$ decay constant & & \\
\hline
\end{tabular}

the glacier length. If the sample transect is covered by ice, production is assumed to cease, while production resumes when the site is ice-free. Nuclide concentrations decrease during periods of ice cover due to glacial erosion of the bedrock surfaces and decay of the nuclides. Production of both ${ }^{10} \mathrm{Be}$ and ${ }^{14} \mathrm{C}$ is dominated by spallation reactions, which are highly attenuated in earth surface materials (e.g. rock, ice); production is essentially nil under as little as $30 \mathrm{~m}$ of ice. A secondary production mechanism is by fast and negative muon interactions. These reactions have a much greater penetration depth, so both nuclides are produced even under ice cover; however, because the fraction of muons in the cosmic ray spectrum is so small, production of ${ }^{10} \mathrm{Be}$ and ${ }^{14} \mathrm{C}$ by muons is not great enough to affect our results measurably (see Goehring et al., 2011).

The accumulation of ${ }^{10} \mathrm{Be}$ and ${ }^{14} \mathrm{C}$ for each sample is described by

exposed : $N_{j}(t)=P_{j}^{s p}(t)+P_{j}^{\mu}(t)+N_{j}(t-1) \mathrm{e}^{-\left(\Delta t \lambda_{j}\right)}$

buried : $N_{j}(t)=N_{j}(t-1) \mathrm{e}^{-(\Delta t \lambda j)} \mathrm{e}^{-\left(\left(\Delta t \varepsilon \rho / \Lambda_{s p}\right)+\left(\Delta t \varepsilon \rho / \Lambda_{\mu_{\text {fast }}}\right)+\left(\Delta t \varepsilon \rho / \Lambda_{\mu-}\right)\right)}$

where $N_{j}(t)$ is the concentration of nuclide $j$ at time $t, P_{j}^{s p}(t)$ is the spallation production rate, $P_{j}^{\mu}(t)$ is the total muon production rate, $\Delta t$ is the length of the time steps ( $1 \mathrm{yr}$ ), and $\lambda_{j}$ is the nuclide decay constant. The burial term has the additional variables of erosion rate $\varepsilon\left(\mathrm{cm} \mathrm{yr}^{-1}\right)$ and attenuation lengths $\left(\Lambda, \mathrm{g} \mathrm{cm}^{-2}\right)$ for spallation, fast muons, and negative muons (Balco and Shuster, 2009). Other key parameters, such as the ${ }^{10} \mathrm{Be}$ and ${ }^{14} \mathrm{C}$ production rates and scaling model used, are discussed in Goehring et al. (2011) and summarized in Table 2.

We determine the best-fitting erosion rates for each paleoclimate scenario by minimizing a misfit statistic between the measured and modeled ${ }^{14} \mathrm{C}$ and ${ }^{10} \mathrm{Be}$. The misfit statistic is defined as

$\mathrm{MF}=\frac{1}{n} \sum_{i=1}^{n}\left(\frac{N_{10, p}-N_{10, \text { meas }}}{\sigma_{N_{10, \text { meas }}}}\right)^{2}+\frac{1}{n} \sum_{i=1}^{n}\left(\frac{N_{14, p}-N_{14, \text { meas }}}{\sigma_{N_{14, \text { meas }}}}\right)^{2}$,

where $n$ is the number of samples, $N_{10, p}$ is the modeled ${ }^{10} \mathrm{Be}$ concentration, $N_{10 \text {,meas }}$ is the measured ${ }^{10} \mathrm{Be}$ concentration, and $\sigma_{N_{10 \text { meas }}}$ is the measurement uncertainty, with corresponding variables for ${ }^{14} \mathrm{C}$ in the second term.
The value of the misfit statistic allows us to evaluate the bestfitting climate scenario. Errors on the resulting erosion rates are determined using a 500-point bootstrap Monte Carlo routine. We assume normally distributed errors on the concentration measurements only, as the uncertainties on the decay constants are very small compared to measurement uncertainty. We also assume zero model error because we are prescribing the exposure history; however, in reality there is likely model imprecision on the order $\pm 10 \%$ of the glacier length. The resulting error is dominated by ${ }^{14} \mathrm{C}$ measurement uncertainty (8-60\%).

\section{Model experiments}

We test three different climate proxies, as well as solar insolation, as templates for variations in the ELA of the Rhone Glacier from the Late Glacial to the present. Proxies used are modeled Summit Greenland temperatures based on $\delta^{18} \mathrm{O}$ of the GISP2 ice core assuming $200 \mathrm{~km}$ of Greenland margin retreat during the Eemian (Cuffey et al., 1995), the $\delta \mathrm{D}$ record from the EPICA Dome C ice core, Antarctica (EPICA Members, 2004), and mean summer solar insolation (June 21-September 21) for $46.5^{\circ} \mathrm{N}$ (Laskar et al., 2004). Finally, we use the $\delta^{18} \mathrm{O}$ record from Dongee Cave, China (Dykoski et al., 2005; Wang et al., 2005). We chose the first three records because they are generally considered benchmarks records of paleoclimate or paleoclimatic forcing.

The fourth record, Dongee Cave, China, $\delta^{18} \mathrm{O}$ as preserved in speleothems (Dykoski et al., 2005; Wang et al., 2005) was also used as a template for paleo ELA. We chose this paleo-record because the long-term fluctuations resemble mean summer insolation, but the record also exhibits higher-frequency climate variability that appears to be highly correlated to climatic variations in the North Atlantic regions, such as $\delta^{18} \mathrm{O}$ from the GISP2 ice core (e.g. Wang et al., 2005; Cheng et al., 2009; Vinther et al., 2009). The North Atlantic-Asian Monsoon link has recently been reproduced in models, where changes in North Atlantic temperature, which is correlated with historical Alpine glacier fluctuations (Denton and Broecker, 2008), lead to changes in $\delta^{18} \mathrm{O}$ as recorded in Chinese speleothems (Legrande and Schmidt, 2009; Pausata et al., 2011). In addition, the Dongee Cave record displays largeamplitude Late Glacial climate fluctuations similar to those recorded in the $\delta^{18} \mathrm{O}$ record of GISP2. Thus, the Dongee Cave $\delta^{18} \mathrm{O}$ record may serve as a plausible template for paleo ELA in the Alps.

Use of these records requires calibration to factors driving glacier changes. Because of complexities of the climate system and the fact that the ELA in the past was likely responding to a combination of temperature and precipitation changes, we use the records to directly force changes in the ELA. We calibrate against the well-documented changes from the LIA to today. This assumes that the relation between ELA and the paleoclimatic record has not changed over time and is linear; we discuss this assumption further below.

To proceed, we first define the sensitivity of the ELA to changes in the measured climate parameters (e.g. $\Delta$ ELA/ $\Delta \delta D$ ):

$\frac{\Delta \mathrm{ELA}}{\Delta \delta D}=\frac{\mathrm{ELA}_{M o d}-\mathrm{ELA}_{L I A}}{\delta D_{M o d}-\delta D_{L I A}}$

where $\mathrm{ELA}_{M o d}$ and ELA $\mathrm{AIA}_{\mathrm{A}}$ are the ELAs required to approximately reproduce the modern and LIA (ca. $1875 \mathrm{CE}$ ) ice extent using the paleo-record, and $\delta D_{M o d}$ and $\delta D_{L I A}$ are the $\delta D$ values from $2000 \mathrm{CE}$ and $1875 \mathrm{CE}$, respectively. Paleo-ELAs are then calculated following:

$\operatorname{ELA}(t)=\frac{\Delta \mathrm{ELA}}{\Delta \delta D}\left(\delta D(t)-\delta D_{M o d}\right)+\mathrm{ELA}_{M o d}$ 
where $\delta D(t)$ is the $\delta D$ value at time $(t)$, for example. It is important to note that we have assumed a linear relationship between variations in the paleo-records and ELA, which may not be correct for the Late Glacial (e.g. Younger Dryas) when the climate system is believed to have been in a transitional and unstable state (e.g. Alley et al., 2001; Broecker et al., 1985), as well as other times during the Holocene. Other relationships between variations in the paleo-records and ELA (e.g. non-linear or time dependent) could be envisioned, but have not been explored in the current study. Use of a different paleo-record ELA relationship is unlikely to have a significant impact on the resultant modeled histories and identification of the most-likely climate scenario, with the exception of the GISP2 model run (see below). All records have been placed on the same time resolution by first applying linear interpolation at one-tenth of a year time steps, thus avoiding any model artifacts from sample intervals approaching glacier response times (order of 100 years or less). Resulting model runs are then resampled at one-year intervals.

\section{Modeling results}

Modeled time-distance diagrams and glacier length histograms of the Rhone Glacier subject to the ELA histories derived from the four paleo-records are shown in Fig. 3. We assess the validity of the model runs in three ways: (1) by comparing the
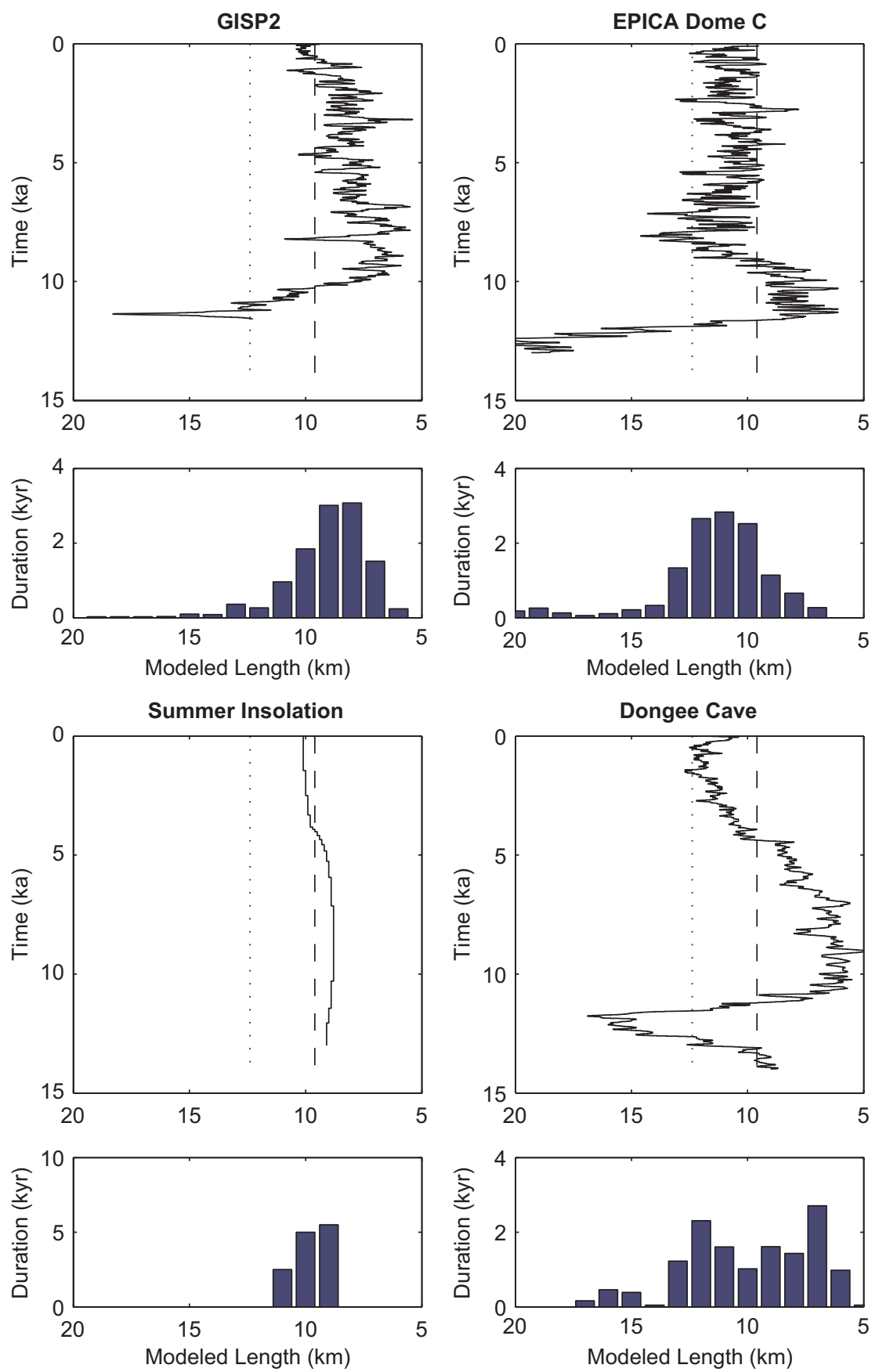

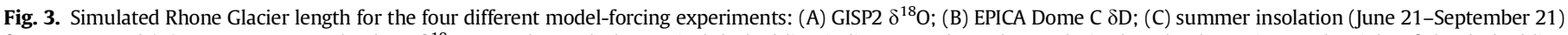

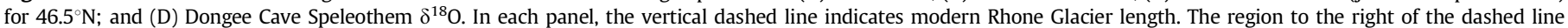
indicates the simulated Rhone Glacier is smaller than modern and vice-versa for the region to the left. Time runs vertically towards the present at the top. 
modeled ${ }^{10} \mathrm{Be}$ and ${ }^{14} \mathrm{C}$ concentrations against measured values (Goehring et al., 2011), (2) by comparing the modeled integrated exposure and burial durations since $11.6 \mathrm{ka}$ against calculated integrated exposure and burial durations (Goehring et al., 2011), and (3) by using a misfit statistic to determine the best-fitting set of glacial erosion rates required by the modeled ice histories to yield the measured ${ }^{10} \mathrm{Be}$ and ${ }^{14} \mathrm{C}$ concentrations.

\subsection{GISP2}

Modeling of the Rhone Glacier using the GISP2 record yields an advance during the YD, the $8.2 \mathrm{ka}$ event, around $4.6 \mathrm{ka}$, before $1 \mathrm{ka}$ and during the LIA, all of which overran our sample sites. However, the advance during the YD does not reach the presumed YD limit at $\sim 22 \mathrm{~km}$ along flowline (Fig. 3; see below for discussion). The remainder of the Holocene displays advances of a few $\mathrm{km}$ that do not overrun our sample sites. Resulting integrated burial and exposure durations since $11.6 \mathrm{ka}$ are thus $2.5 \mathrm{kyr}$ and $9.1 \mathrm{kyr}$, respectively. In contrast, integrated burial and exposure durations from Goehring et al. (2011) are $4.5 \mathrm{kyr}$ and $6.5 \mathrm{kyr}$, respectively. Notably, there is no pronounced late Holocene readvance commencing around 3-4 ka, which is suggested for the Alps by Ivy-Ochs et al. (2009).

As an example, we have calculated ${ }^{10} \mathrm{Be}$ and ${ }^{14} \mathrm{C}$ concentrations for one sample (Rho-9) by specifying the erosion rate. We use the erosion rate $\left(0.03 \mathrm{~mm} \mathrm{yr}^{-1}\right)$ from Goehring et al. (2011), as this should provide a reasonable estimate of the erosion for this sample during ice cover. Fig. 4 shows the ${ }^{10} \mathrm{Be}$ and ${ }^{14} \mathrm{C}$ history, as well as the ratio of the two nuclides. Because of the persistent exposure during the Holocene, the modeled values significantly overestimate the measured values. The erosion rate that the samples experienced would need to be significantly increased to unreasonably high values (most samples $>0.5 \mathrm{~mm} \mathrm{yr}^{-1}$, up to
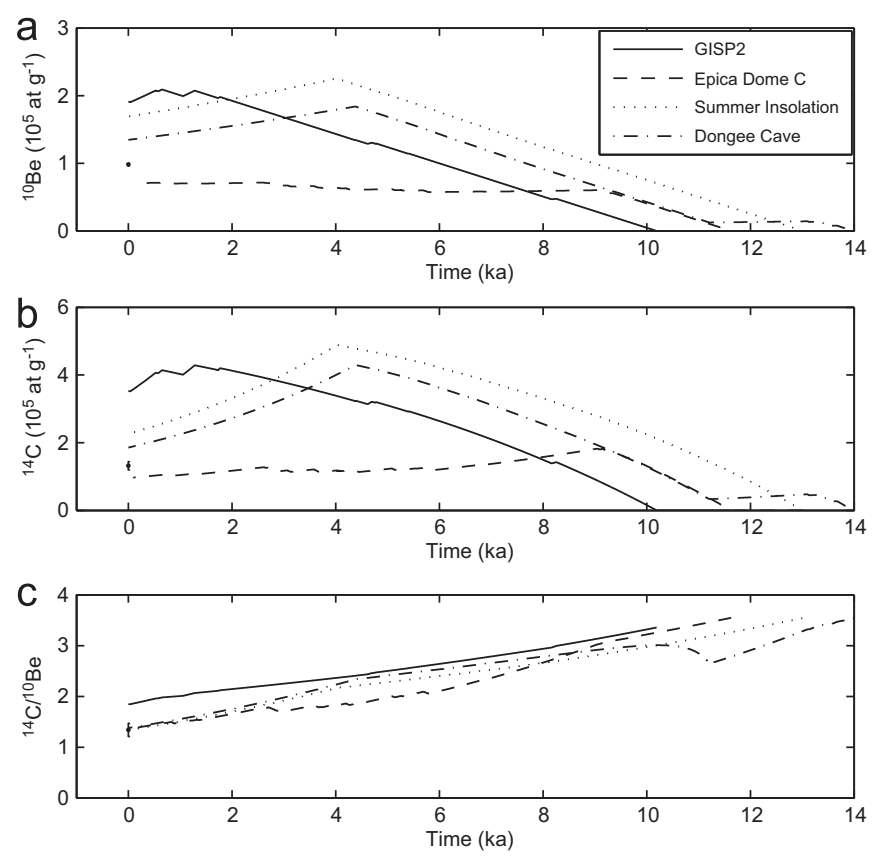

Fig. 4. Example of $(A){ }^{10} \mathrm{Be}$; (B) ${ }^{14} \mathrm{C}$; and $(\mathrm{C}){ }^{14} \mathrm{C} /{ }^{10} \mathrm{Be}$, based on simulated Rhone Glacier lengths for four model experiments for sample Rho-9. Resulting concentrations and isotope ratio is dependent on glacial erosion rate, in this case selected based on results presented in Goehring et al. (2011). Measured ${ }^{10} \mathrm{Be},{ }^{14} \mathrm{C}$, and ${ }^{14} \mathrm{C} /{ }^{10} \mathrm{Be}$ are shown by solid circle, measurement uncertainty is shown, but is typically smaller than the symbol. Before determination of best-fitting glacial erosion rate, use of the Dongee Cave speleothem record yields the best agreement between simulated measured concentrations and ratios.
$2.6 \mathrm{~mm} \mathrm{yr}^{-1}$ ) to yield the correct concentrations. Similar plots for all other samples are shown in Supplementary Figs. S1 and S2.

\subsection{EPICA Dome C}

In contrast to the GISP2 results, burial of the sample sites characterizes the EPICA Dome $C$ derived time-distance history. The most significant period of exposure occurs just after the YD during the Preboreal period. During most of the Holocene, the modeled Rhone Glacier terminus is just beyond the sample sites. Very short-term fluctuations sometimes result in sample sites being exposed, most notably around $2.7 \mathrm{ka}$. Integrated burial and exposure durations are $8.4 \mathrm{kyr}$ and $3.2 \mathrm{kyr}$, respectively. Modeled concentrations of ${ }^{10} \mathrm{Be}$ and ${ }^{14} \mathrm{C}$ based on the EPICA Dome $\mathrm{C}$ results are much lower than measured values. Erosion would need to be negative (aggradation; Fig. 4) to increase the modeled concentrations to the measured concentrations, an unphysical result.

\subsection{Insolation}

Calibration to the LIA-Modern signal cannot be used for orbitally controlled insolation; the LIA is too short to have been notably influenced by Milankovitch processes. Instead, we use a linear scaling for the entire Holocene; that shown in Fig. $3 \mathrm{C}$ assigns the peak Holocene summer insolation for $46.5^{\circ} \mathrm{N}$ to the modern ELA, and the minimum Holocene insolation to the LIA ELA. Resulting integrated burial and exposure durations are $4.0 \mathrm{kyr}$ and $7.6 \mathrm{kyr}$, respectively. The modeled history provides a reasonable match to observed ${ }^{10} \mathrm{Be}$ and ${ }^{14} \mathrm{C}$ concentrations for possible reasonable erosion rates ( $\sim 2 \times$ those in Goehring et al., 2011; Fig. 4). However, it fails to match the modern terminus position. Furthermore, any scaling of ELA against insolation that does match the modern terminus will fail to match the observed ${ }^{10} \mathrm{Be}$ and ${ }^{14} \mathrm{C}$ concentrations for reasonable erosion rates; current insolation is near the extreme low for the Holocene, but the ${ }^{14} \mathrm{C}$ and ${ }^{10} \mathrm{Be}$ concentrations require that the total times of coverage and exposure were sub-equal.

\subsection{Dongee Cave}

The resulting time-distance history shows a large YD advance from a position near the modern terminus (Fig. 3). Following the YD, the modeled Rhone Glacier retreated to somewhere behind the modern position, exposing the sample sites. There are small readvances during the early Holocene, notably around $8.2 \mathrm{ka}$, but nothing exceeding the modern ice extent. Beginning just after $5 \mathrm{ka}$, the modeled glacier begins to advance, overriding the sample sites. Not until the end of the LIA, which is well represented in the Dongee Cave model run, does the glacier begin to retreat notably again. The modeled behavior is in excellent agreement with the general understanding of Holocene glacier fluctuations in the Alps (Ivy-Ochs et al., 2009). The integrated burial duration is $4.8 \mathrm{kyr}$, while integrated exposure duration is $6.8 \mathrm{kyr}$, in excellent agreement with the integrated durations presented in Goehring et al. (2011).

As a consequence of the modeled glacier lengths that appear to be in agreement with geologic evidence, the modeled ${ }^{10} \mathrm{Be}$ and ${ }^{14} \mathrm{C}$ concentrations are also in good agreement with the measured concentrations (Fig. 4). Although the ${ }^{10} \mathrm{Be}$ and ${ }^{14} \mathrm{C}$ concentrations are slightly overestimated, slight adjustment of the erosion rates yields close matches for values fully consistent with physical understanding.

\subsection{Minimization results}

The best-fit erosion rates for the insolation and Dongee Cave model runs are shown in Table 3. Minimizations for the GISP2 and 
Table 3

Resulting best-fit erosion rates for individual samples. Also shown are the erosion rates from Goehring et al. (2011).

\begin{tabular}{|c|c|c|c|c|c|}
\hline \multicolumn{6}{|c|}{ Erosion rate $\left(\mathrm{mm} \mathrm{yr}^{-1} \pm 1 \sigma\right)$} \\
\hline Sample & GISP2 & EPICA Dome C & Summer insolation & Dongee Cave & Goehring et al. (2011) \\
\hline Rho-1 & $1.118 \pm 0.016$ & $0.071 \pm 0.002$ & $0.279 \pm 0.004$ & $0.235 \pm 0.003$ & $0.33 \pm 0.151$ \\
\hline Rho-2 & $0.992 \pm 0.013$ & $0.053 \pm 0.002$ & $0.248 \pm 0.003$ & $0.206 \pm 0.003$ & $0.25 \pm 0.125$ \\
\hline Rho-3 & $0.787 \pm 0.054$ & $0.023 \pm 0.007$ & $0.194 \pm 0.013$ & $0.155 \pm 0.012$ & $0.23 \pm 0.106$ \\
\hline Rho-4 & $0.374 \pm 0.018$ & $-0.032 \pm 0.002$ & $0.092 \pm 0.005$ & $0.059 \pm 0.005$ & $0.11 \pm 0.046$ \\
\hline Rho-5 & $2.625 \pm 0.071$ & $0.344 \pm 0.018$ & $0.604 \pm 0.013$ & $0.542 \pm 0.012$ & $0.66 \pm 0.293$ \\
\hline Rho-6 & $0.703 \pm 0.010$ & $0.013 \pm 0.001$ & $0.176 \pm 0.003$ & $0.138 \pm 0.003$ & $0.07 \pm 0.032$ \\
\hline Rho-7 & $0.755 \pm 0.011$ & $0.020 \pm 0.002$ & $0.189 \pm 0.003$ & $0.150 \pm 0.003$ & $0.12 \pm 0.056$ \\
\hline Rho-8 & $0.480 \pm 0.010$ & $-0.019 \pm 0.001$ & $0.118 \pm 0.003$ & $0.084 \pm 0.002$ & $0.03 \pm 0.014$ \\
\hline Rho-9 & $0.460 \pm 0.010$ & $-0.022 \pm 0.001$ & $0.113 \pm 0.002$ & $0.079 \pm 0.003$ & $0.04 \pm 0.019$ \\
\hline Rho-10 & $0.418 \pm 0.010$ & $-0.027 \pm 0.001$ & $0.102 \pm 0.003$ & $0.069 \pm 0.002$ & $0.03 \pm 0.014$ \\
\hline Rho-11 & $0.333 \pm 0.011$ & $-0.041 \pm 0.002$ & $0.076 \pm 0.003$ & $0.046 \pm 0.003$ & $0.02 \pm 0.009$ \\
\hline Total misfit & 522.3 & 88.86 & 34.02 & 13.65 & - \\
\hline
\end{tabular}

EDC model runs failed to produce physically plausible solutions (very high or negative erosion rates), so these are excluded from further discussion. The insolation- and Dongee Cave-driven erosion rates are very similar to each other and to those presented in Goehring et al. (2011). As expected, based on the measured ${ }^{14} \mathrm{C}$ and ${ }^{10} \mathrm{Be}$ concentrations, erosion rates increase towards the center of the glacial trough. Use of the Dongee Cave record yields the best fit; however, results of the insolation model run also yield acceptable results for erosion rates, although failing to match the LIA-modern length history.

\section{Discussion}

The failure of the GISP2 temperature record could arise from any of several causes. One is the well-known frequency-dependence of the calibration of isotopic ratios against temperature (e.g. Cuffey et al., 1995), such that an isotopic shift of given size from middle to late Holocene indicates a larger temperature change than the same isotopic shift over a millennial oscillation. Another is the observation that the elevation of the Greenland ice sheet changed through time (Vinther et al., 2009), thus changing the calibration of isotopic ratios against temperature through time. One could correct for both of these observations in various ways, and such corrections would shift the record to more closely resemble northern hemisphere summer insolation with superimposed high-frequency variation (and to more closely resemble the Dongee Cave record). The isotopic frequency-dependence may also explain the YD length mismatch between the modeled and observed glacier lengths, as the ELA- $\delta^{18} \mathrm{O}$ relationship was determined for modern and LIA times. ELA- $\delta^{18} \mathrm{O}$ scaling established in such a manner to give the observed YD length leads to an unrealistically small glacier during the Holocene; the sample sites are always exposed, which is not allowed by our ${ }^{14} \mathrm{C}$ and ${ }^{10} \mathrm{Be}$ measurements.

Ultimately, our modeling of the Rhone Glacier indicates that climate forcing with long-term behavior resembling local (or more broadly, mid to high northern latitude) summer insolation yields ${ }^{10} \mathrm{Be}$ and ${ }^{14} \mathrm{C}$ concentrations most similar to measured values for all samples. This first-order result suggests that the response of the Rhone Glacier, and likely other glaciers of the Alps, during the Holocene was primarily temperature-driven via changes in summer insolation. As discussed above, modeled ice extent is generally less than modern during the early to mid Holocene. Modeled ice extent then increases to its present position and beyond beginning ca. 4-5 ka. Our model results are in agreement with observations of ice extent increasing throughout the Alps 3-4 ka (Holzhauser et al., 2005; Ivy-Ochs et al., 2009).
While the use of insolation yields results that match what is generally believed to be the overall behavior of the Rhone Glacier during the Holocene, the suggested high frequency variations (Ivy-Ochs et al., 2009) are lacking. This is particularly evident during the Late Glacial and earliest Holocene, when much cooler temperatures occurred throughout the Alps during short-term climate events (e.g. YD, 8.2 ka event; Finsinger and Tinner, 2007; Heiri et al., 2003; Ilyashuk et al., 2011; Vollweiler et al., 2006; Wick et al., 2003). These cold events occurred during intervals of high insolation, and their abruptness does not fit with smoothly varying insolation. In addition, the well-documented LIA advance throughout the Alps is absent from the insolation model results. The use of the Dongee Cave record as forcing in our model yields changes of Rhone Glacier extent that over the long-term resemble an insolation response, and over shorter time periods resemble known climate events (e.g. YD, LIA).

Using the Dongee Cave record, the modeled extent and timing of ice margin fluctuations match those indicated by the distribution of radiocarbon dates on glacially overrun trees from numerous glacial troughs throughout the Alps (Fig. 5; Hormes et al., 1998, 2001, 2006; Joerin et al., 2006, 2008; Nicolussi and Patzelt, 2000). In agreement with our modeled ice extents, numerous trees that lived in currently glaciated terrain and were then overrun by glaciers date from the early Holocene, while the late Holocene largely lacks evidence of tree growth in areas currently glacially covered. The pattern of modeled ice extents, small in the early Holocene and becoming progressively larger with superimposed fluctuations, also agrees well with a record of glacier activity (i.e. glacier size) inferred from median grain size in Lake Silvaplana, Switzerland (Leemann and Niessen, 1994). Finally, reconstructed surface elevations of the Ober Grindelwald Glacier (Luetscher et al., 2011), based on speleothem mineralogy, show excellent agreement with our overall trend in glacier extent during the Holocene. Our modeled ice extent and the speleothem record also display similar rapid glacier fluctuations, including fluctuations during the $8.2 \mathrm{ka}$ event and just after $6 \mathrm{ka}$, and a large change in extent towards larger glaciers just before 4 ka. The latter event may possibly be coeval with a glacier advance identified in the North American Cordillera at 4.2 ka (e.g. Menounos et al., 2008; Osborn et al., 2007), implying at least hemispheric synchronicity.

\section{Conclusions}

The combined approach of surface exposure dating with numerical ice flow models yields more information about past glacier fluctuations than either method alone. We evaluate models of the Rhone Glacier during the Holocene forced by four 


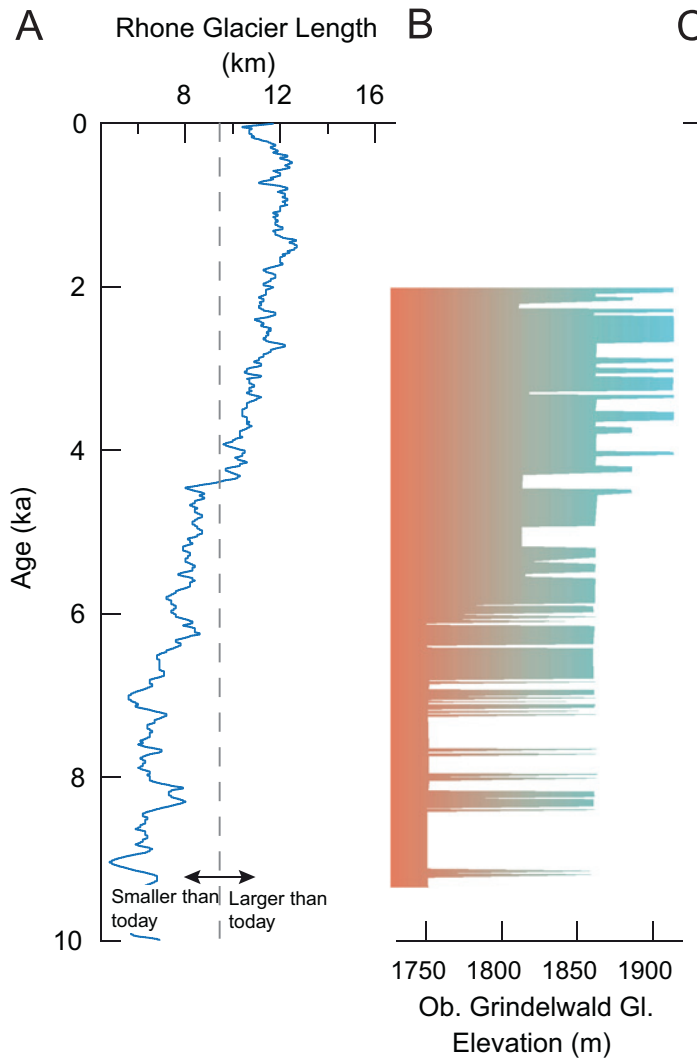

C Trees/Peat

$\mathrm{D}$

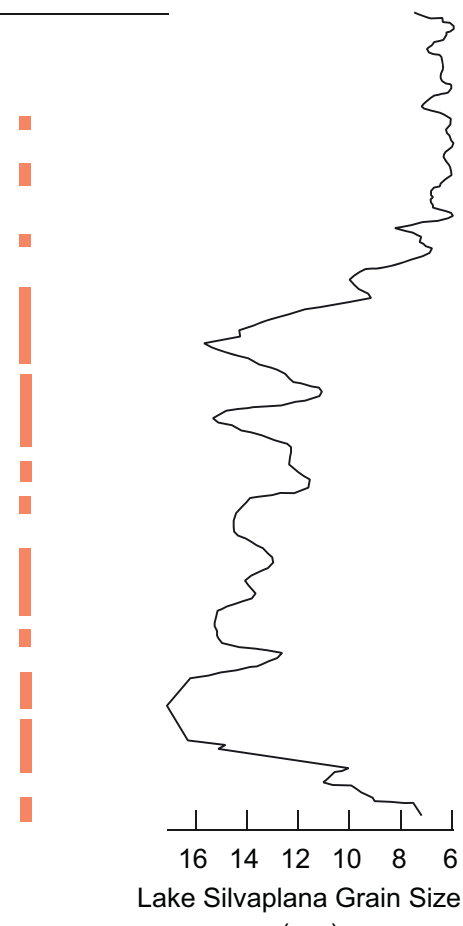

$(\mu \mathrm{m})$

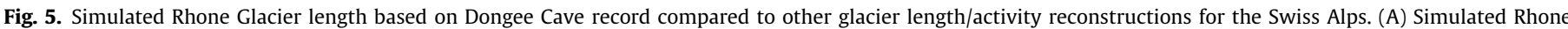

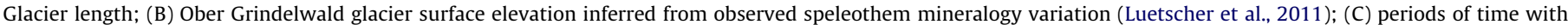

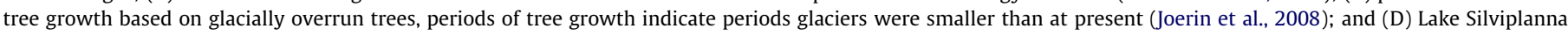

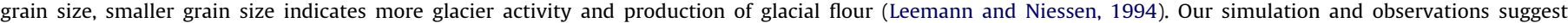
generally increasing glacier size/activity during the late Holocene and relatively small/inactive glaciers during the early Holocene.

different climate records against measurements of ${ }^{10} \mathrm{Be}$ and ${ }^{14} \mathrm{C}$, and suggest that climate variations resembling the $\delta^{18} \mathrm{O}$ record from Dongee Cave, China, yield the most likely time-distance history of the Rhone Glacier. Other climate scenarios can be used; however, unrealistic erosion rates are required. The main conclusion is that glaciers in the Alps primarily responded to changes in insolation during the Holocene, were smaller than today during the early Holocene when insolation was relatively high, and became larger during the mid to late Holocene. Superimposed on the first-order insolation response were shorter, sometimes large amplitude, length changes in response to short-lived climate events such as the Medieval Warm Period and the LIA. The LIA represents the largest extent of the Rhone Glacier since the early Holocene. Ice extent remained in a position smaller than today until approximately $5 \mathrm{ka}$. After $5 \mathrm{ka}$, the Rhone Glacier was larger than today, but smaller than its LIA maximum extent. The present extent of the Rhone Glacier therefore likely represents its smallest since the middle Holocene and potential climate warming will lead to further rapid retreat of the Rhone Glacier.

\section{Acknowledgments}

We thank members of the Penn State Ice Group, Wally Broecker, and Christian Schlüchter for thoughtful discussions during completion of this work. BMG acknowledges generous support from the NOAA Climate and Global Change Postdoctoral Fellowship Program. RBA and DAV acknowledge partial support from NSF 0424589. Suggestions from two anonymous reviewers improved the manuscript.

\section{Appendix A. Supporting information}

Supplementary data associated with this article can be found in the online version at http://dx.doi.org/10.1016/j.epsl.2012.07.027.

\section{References}

Alley, R., Anandakrishnan, S., Jung, P., 2001. Stochastic resonance in the North Atlantic. Paleoceanography 16, 190-198.

Balco, G., Briner, J., Finkel, R.C., Rayburn, J.A., Ridge, J.C., Schaefer, J.M., 2009 Regional beryllium-10 production rate calibration for Late-Glacial Northeastern North America. Quat. Geochron. 4, 93-107.

Balco, G., Shuster, D.L., 2009. Production rate of cosmogenic ${ }^{21} \mathrm{Ne}$ in quartz estimated from ${ }^{10} \mathrm{Be},{ }^{26} \mathrm{Al}$, and ${ }^{21} \mathrm{Ne}$ concentrations in slowly eroding Antarctic bedrock surfaces. Earth Planet. Sci. Lett. 281, 48-58.

Broecker, W.S., Peteet, D.M., Rind, D., 1985. Does the ocean-atmosphere systerm have more than one stable mode of operation? Nature 315, 21-26.

Chen, J., Funk, M., 1990. Mass balance of Rhonegletscher during 1882/83-1986/87. J. Glaciol. 36, 199-209.

Cheng, H., Edwards, R.L., Broecker, W.S., Denton, G.H., Kong, X., Wang, Y., Zhang, R. Wang, X., 2009. Ice age terminations. Science 326, 248-252.

Cuffey, K.M., Clow, G.D., Alley, R.B., Stuiver, M., Waddington, E.D., Saltus, R.W. 1995. Large Arctic temperature change at the Wisconsin-Holocene glacial transition. Science 270, 455-458.

Denton, G., Broecker, W., 2008. Wobbly ocean conveyor circulation during the Holocene? Quat. Sci. Rev. 27, 1939-1950.

Dugan, B., Lifton, N., Jull, A.J.T., 2008. New production rate estimates for in situ cosmogenic C-14. Geochim. Cosmochim. Acta A 72, 231.

Dykoski, C., Edwards, R., Cheng, H., Yuan, D., Cai, Y., Zhang, M., Lin, Y., Qing, J., An Z., Revenaugh, J., 2005. A high-resolution, absolute-dated Holocene and deglacial Asian Monsoon record from Dongge Cave, China. Earth Planet. Sci. Lett. 233, 71-86

Finsinger, W., Tinner, W., 2007. Pollen and plant macrofossils at Lac de Fully (2135 $\mathrm{m}$ a.s.l.): Holocene forest dynamics on a highland plateau in the Valais, Switzerland. Holocene 17, 1119-1127. 
Goehring, B.M., Schaefer, J.M., Schluechter, C., Lifton, N.A., Finkel, R.C., Jull, A.J.T. Akçar, N., Alley, R.B., 2011. The Rhone Glacier was smaller than today for most of the Holocene. Geology 39, 679-682.

Gosse, J.C., Phillips, F.M., 2001. Terrestrial in situ cosmogenic nuclides: theory and application. Quat. Sci. Rev. 20, 1475-1560.

Hantke, R., 1978. The Rhone Glacier Moraines in the uppermost valley. In: Schlüchter, C. (Ed.), Guidebook for the Excursion of the INQUA Commission on Genesis and Lithology of Quaternary Deposits, Zurich, pp. 42-45.

Heiri, O., Lotter, A., Hausmann, S., Kienast, F., 2003. A chironomid-based Holocene summer air temperature reconstruction from the Swiss Alps. Holocene 13, 477-484.

Heuberger, H., 1966. Gletschergeschichtliche Untersuchungen in den Zentralalpen zwischen Sellrain- und Ötztal. Wiss. Alpenvereinshefte 20,1-126.

Heuberger, H., 1968. Die Alpengletscher im Spät- und Postglazial. Eiszeitalter Ggw. $19,270-275$.

Holzhauser, H., Magny, M., Zumbuuhl, H., 2005. Glacier and lake-level variations in west-central Europe over the last 3500 years. Holocene 15, 789.

Hormes, A., Beer, J., Schlüchter, C., 2006. A geochronological approach to understanding the role of solar activity on Holocene glacier length variability in the Swiss Alps. Geogr. Ann. 88, 281-294.

Hormes, A., Müller, B.U., Schlüchter, C., 2001. The Alps with little ice: evidence for eight Holocene phases of reduced glacier extent in the Central Swiss Alps. Holocene 11, 255-265.

Hormes, A., Schluchter, C., Stocker, T., 1998. Minimal extension phases of Unteraarglacier (Swiss Alps) during the Holocene based on C-14 analysis of wood. Radiocarbon 40, 809-817.

Ilyashuk, E.A., Koinig, K.A., Heiri, O., Ilyashuk, B.P., Psenner, R., 2011. Holocene temperature variations at a high-altitude site in the Eastern Alps: a chironomid record from Schwarzsee ob Solden, Austria. Quat. Sci. Rev. 30, 176-191.

Ivy-Ochs, S., Kerschner, H., Maisch, M., Christl, M., Kubik, P.W., Schluchter, C., 2009. Latest Pleistocene and Holocene glacier variations in the European Alps. Quat. Sci. Rev. 28, 2137-2149.

Joerin, U., Stocker, T.F., Schlüchter, C., 2006. Multicentury glacier fluctuations in the Swiss Alps during the Holocene. Holocene 16, 697-704.

Joerin, U.E., Nicolussi, K., Fischer, A., Stocker, T., Schluechter, C., 2008. Holocene optimum events inferred from subglacial sediments at Tschierva Glacier, Eastern Swiss Alps. Quat. Sci. Rev. 27, 337-350.

Laskar, J., Robutel, P., Joutel, F., Gastineau, M., Correia, A., Levrard, B., 2004. A longterm numerical solution for the insolation quantities of the Earth. Astron. Astrophys. 428, 261-285.

Leemann, A., Niessen, F., 1994. Holocene glacial activity and climatic variations in the Swiss Alps: reconstructing a continuous record from proglacial lake sediments. Holocene 4, 259-268.

Legrande, A.N., Schmidt, G.A., 2009. Sources of Holocene variability of oxygen isotopes in paleoclimate archives. Climate Past 5, 441-455.

Licciardi, J.M., Schaefer, J.M., Taggart, J.R., Lund, D.C., 2009. Holocene glacier fluctuations in the Peruvian Andes indicate northern climate linkages. Science 325, 1677-1679.

Lifton, N.A., Jull, A.J.T., Quade, J., 2001. A new extraction technique and production rate estimate for in situ cosmogenic ${ }^{14} \mathrm{C}$ in quartz. Geochim. Cosmochim. Acta 65, 1953-1969.

Luetscher, M., Hoffmann, D.L., Frisia, S., Spötl, C., 2011. Holocene glacier history from alpine speleothems, Milchbach Cave, Switzerland. Earth Planet. Sci. Lett. 302, 95-106.

Mann, M.E., Zhang, Z.H., Rutherford, S., Bradley, R.S., Hughes, M.K., Shindell, D., Ammann, C., Faluvegi, G., Ni, F., 2009. Global signatures and dynamical origins of the Little Ice Age and Medieval Climate Anomaly. Science 326, 1256-1260.

Members, E.C., 2004. Eight glacial cycles from an Antarctic ice core. Nature 429, 623-628.

Menounos, B., Clague, J.J., Osborn, G., Luckman, B.H., Lakeman, T.R., Minkus, R., 2008. Western Canadian glaciers advance in concert with climate change circa 4.2 ka. Geophys. Res. Lett. 35, L07501.
Miller, G.H., Brigham-Grette, J., Alley, R.B., Anderson, L., Bauch, H.A., Douglas, M.S.V., Edwards, M.E., Elias, S.A., Finney, B.P., Fitzpatrick, J.J., Funder, S.V., Herbert, T.D., Hinzman, L.D., Kaufman, D.S., MacDonald, G.M., Polyak, L., Robock, A., Serreze, M.C., Smol, J.P., Spielhagen, R., White, J.W.C., Wolfe, A.P., Wolff, E.W., 2010. Temperature and precipitation history of the Arctic. Quat. Sci. Rev. 29, 1679-1715.

Nesje, A., Matthews, J.A., Dahl, O., Berrisford, M.S., Andersson, C., 2001. Holocene glacier fluctuations of Flatebreen and winter-precipitation changes in the Jostedalsbreen region, Western Norway, based on glaciolacustrine sediment records. Holocene 11, 267-280.

Nicolussi, K., Patzelt, G., 2000. Discovery of early Holocene wood and peat on the forefield of the Pasterze Glacier, Eastern Alps, Austria. Holocene 10, 191.

Nishiizumi, K., Imamura, M., Caffee, M.W., Southon, J.R., Finkel, R.C., McAninch, J., 2007. Absolute calibration of ${ }^{10}$ Be AMS standards. Nucl. Instrum. Methods 258, 403-413.

Oerlemans, J., 2005. Extracting a climate signal from 169 glacier records. Science 308, 675-677.

Osborn, G., Menounos, B., Koch, J., Clague, J., Vallis, V., 2007. Multi-proxy record of Holocene glacial history of the Spearhead and Fitzsimmons ranges, Southern Coast Mountains, British Columbia. Quat. Sci. Rev. 26, 479-493.

Pausata, F., Battisti, D.S., Niscancioglu, K.H., Bitz, C.M., 2011. Chinese stalagmites: proxies for the Indian Monsoon response to an archetypal Heinrich event. Nat. Geosci. 4 (7), 474-480.

Schaefer, J., Denton, G., Kaplan, M., Putnam, A., Finkel, R., Barrell, D., Andersen, B., Schwartz, R., Mackintosh, A., Chinn, T., Schluchter, C., 2009. High-frequency Holocene glacier fluctuations in New Zealand differ from the northern signature. Science 324, 622-625.

Stroeven, A., van de Wal, R., Oerlemans, J., 1989. Historic front variations of the Rhone Glacier: simulation with an Ice Flow Model. In: Oerlemans, J. (Ed.), Glacier Fluctuations and Climatic Change. Kluwer Academic Publishers, Dordrecht.

Sugiyama, S., Bauder, A., Zahno, C., Funk, M., 2007. Evolution of Rhonegletscher, Swizterland, over the past 125 years and in the future: application of an improved flowline model. Ann. Glaciol. 46, 268-274.

Vacco, D.A., Alley, R.B., Pollard, D., 2009. Modeling dependence of moraine deposition on climate history: the effect of seasonality. Quat. Sci. Rev. 28, 639-646.

Vacco, D.A., Alley, R.B., Pollard, D., 2010a. Glacial advance and stagnation caused by rock avalanches. Earth Planet. Sci. Lett. 294, 123-130.

Vacco, D.A., Alley, R.B., Pollard, D., Reusch, D.B., 2010b. Numerical modeling of valley glacier stagnation as a paleoclimatic indicator. Quat. Res. 73, 403-409.

Vinther, B.M., Buchardt, S.L., Clausen, H.B., Dahl-Jensen, D., Johnsen, S.J., Fisher, D.A., Koerner, R.M., Raynaud, D., Lipenkov, V., Andersen, K.K., Blunier, T., Rasmussen, S.O., Steffensen, J.P., Svensson, A.M., 2009. Holocene thinning of the Greenland ice sheet. Nature 461, 385-388.

Vollweiler, N., Scholz, D., Mühlinghaus, C., Mangini, A., Spötl, C., 2006. A precisely dated climate record for the last 9 kyr from three high alpine stalagmites, Spannagel Cave, Austria. Geophys. Res. Lett. 33, L20703.

Wallinga, J., van de Wal, R.S.W., 1998. Sensetivity of Rhonegletscher, Switzerland, to climate change: experiments with a one-dimensional flowline model. J. Glaciol. 44, 383-393.

Wang, Y., Cheng, H., Edwards, R., He, Y., Kong, X., An, Z., 2005. The Holocene Asian Monsoon: links to solar changes and North Atlantic climate. Science.

Ward, D.J., Anderson, R.S., Guido, Z.S., Briner, J.P., 2009. Numerical modeling of cosmogenic deglaciation records, Front Range and San Juan mountains, Colorado. J. Geophys. Res. 114, 1-21.

Wick, L., van Leeuwen, J., van der Knaap, W., Lotter, A., 2003. Holocene vegetation development in the catchment of Sagistalsee (1935 m a.s.l.), a small lake in the Swiss Alps. J. Paleolimnol. 30, 261-272.

Zahno, C., 2004. Der Rhonegletscher in Raum and Zeit: Neue Geometrische und Klimatische Ensichten. ETH Zürich, Zürich. 